\title{
AN INTERGENERATIONAL PERSPECTIVE ON RISK AND PROTECTIVE FACTORS IN MULTI-PROBLEM POOR FAMILES LIVING IN CAPE TOWN
}

\section{Jackie Hope, Mariette van der Merwe}

\section{INTRODUCTION}

At the time of the research the first author was employed as a social worker at a welfare organisation in the Cape Peninsula with a case load of over 300 clients. About 30 of these cases were multi-problem families who had been receiving social work services over at least three generations. The concern was that these multi-problem poor families seemed to be immobilised and found it difficult to break out of the cycle of poverty and welfare dependency.

Sousa, Ribeiro and Rodriques (2007:54) define multi-problem families as those that present with severe and multiple psychosocial problems for more than a year. Characteristics of multi-problem families include: unemployment, incarceration, substance abuse, child antisocial behaviour and resistance to intervention (Possick, 2005:407; Sharlin \& Shamia, 2000:5; Sousa et al., 2007:54).

This notion of a cycle of poverty has plagued researchers for years. Jordan (1978:3) emphasises the intergenerational cycle of poverty and states that "research indicated that 'problem families' (dependent on the welfare system) give rise to children who form a new generation of "problem families"" and that "parents who were themselves deprived in childhood become in turn parents of another generation of deprived children" (Jordan, 1978:120). According to Sousa (2005:164,165), multi-problem families are characterised by "a chain of severe problems affecting an indeterminate number of members".

Sousa and Eusebio (2005:366) state that little is known about why multi-problem families are involved with social services. Goldenberg and Goldenberg (2004:8) suggest that the narratives of families provide insights into their interactive patterns. As such, this research was conducted by exploring the narrative accounts by family members of their chronosystem and current life issues, focusing on risk and protective factors. According to Härkönen (2007:13), the chronosystem refers to the pattern of events, transitions, change, history and development that occurs over time within these systems (e.g., divorce, death of a parent, etc.). In this research, note was also taken of exceptions, where family members were able to cope and managed to initiate a break from the cycles of deprivation.

\section{RESEARCHDESIGN AND METHODOLOGY}

This section elaborates on the research approach and design, data collection, overview of participants, and the ethical considerations of the research. 


\section{Research approach}

A qualitative approach was utilised to describe phenomena from the participants' point of view (Fouché \& Delport in De Vos, Strydom, Fouché \& Delport, 2011:64-65; Leedy $\&$ Ormrod, 2005:94-97). Applied, exploratory and descriptive goals were adopted as the research aimed to obtain an intergenerational perspective on the risk and protective factors in multi-problem poor families living in Cape Town.

\section{The research design}

The case study research design (Nieuwenhuis in Maree, 2007:75-76) was utilised as the researcher became engaged in the activities of the participants to "gain intimate familiarity with their social worlds and to identify patterns in the participants' lives" (Fouché \& Schurink, 2011:320-321). Case studies were used to explore the subjective meaning the participants gave to their experiences (Fouché \& Schurink, 2011:320) of the cycle of poverty and welfare dependency.

\section{Data collection}

Data were gathered through in-depth semi-structured interviews with participants, which were recorded and then transcribed. Field notes and document analysis of participants' case files from the local social welfare office were also utilised to gain a rich account of the family's history and for data triangulation. A semi-structured interview guide and certain tools (ecomap, genogram, life line and worry worms) were used during interviews to aid data collection (Malindi \& Theron, 2011:105-116; Mitchell, Theron, Stuart, Smith \& Campbell, 2011:19-34). Holloway and Wheeler (1998:55) explain that an interview-guide is used when the researcher makes use of questions that are included in an interview guide (not a schedule or questionnaire as in quantitative research), with a focus on the issues to be covered. Questions about each issue are asked in an open-ended manner (Tutty, Rothery \& Grinnell, 1996:56).

\section{Selection of participants}

Interviews were conducted with the participants who were purposively sampled (Strydom in De Vos et al., 2011:232) and who met the following selection criteria: poor families living in the Cape Peninsula area; families that were currently involved with social services due to current social issues; and families who had been struggling with social issues over three or more generations.

The seven participants were all women, and of the seven, three were white and four were coloured. The participants resided in the Maitland, Albow Gardens and Brooklyn communities in the Cape Peninsula. Five spoke Afrikaans as their first language and two were English speaking. Early in the empirical investigation it was already clear that themes were repeating, which lead to the conclusion that saturation of data was reached after seven in-depth interviews with these participants.

All participants were involved with social services for various reasons. Three participants had their children removed from their care and placed in children's homes. Three of the participants were the foster parents to their grandchildren as the middle 
generation was involved with substance abuse and had neglected their children. Sexual abuse featured in four of the families.

\section{Ethical considerations}

Ethical considerations were guided by the researchers' profession as social workers, who adhere to the South African Council for Social Service Professions' code of ethics. Ethical considerations as set out by Whittaker (2012:114) and Welman, Kruger and Mitchell (2005:11) including confidentiality, doing no harm and obtaining informed consent, were core features from the onset of the research in terms of the research process, selection of participants, interviewing and data analysis. All participants voluntarily signed a consent form to participate in the research, and provided written consent for the researchers to use their files at the social welfare office. Participants needed to disclose intimate details about their past and during the interviews it was found that some of the participants became emotional. Participants were offered further counselling services by social workers at the local welfare office.

\section{RESEARCHFINDINGS}

Interviews were recorded and transcribed for analysis according to data analysis methods as proposed by Schurink, Fouché and de Vos (in De Vos et al., 2011:404) and thematic analysis as described by Whittaker (2012:92-98) and Braun and Clarke (2006:88-93). The interview transcriptions were coded and various themes emerged, which are presented below.

\section{Theme 1: Experiences of poverty}

Individuals exist within a field which is made up of family, culture, and religious and school/work systems (Yontef, 1993:297). All parts of the field are interconnected and mutually influencing (Härkönen, 2007; Minuchin, Colapinto \& Minuchin, 2007). As such, it was relevant to consider the participants' environmental context.

This research was conducted in the Western Cape of South Africa. The Social Profile of South Africa 2002-2009 (STATSSA, 2009) indicated that over 40\% of all infants live in overcrowded houses with seven or more people, and that a grandparent was the household head in almost $60 \%$ of cases. This was found to be true of the research participants included in the study reported on, as most of them are the grandparents or even great-grandparents who are caring for their grandchildren and great-grandchildren and rely on government grants to support the family. The STATSSA (2009) profile indicates that $32 \%$ of South African children live with both their biological parents and a quarter of children do not live with either of their biological parents. A theme that emerged in the research was that of a missing generation of current parents in the families, which seems evident in the statistics as well. The STATSSA (2009) statistics also indicate that a large proportion of children fail to pass Grade 7 by the age of 15 years. Lack of money, poor academic performance, and teenage pregnancy are cited as reasons for this trend. Research participants and their families consistently presented with early school dropout and high rates of teenage pregnancy in each generation. 
Oosthuizen and Nieuwoudt's (2002) poverty profile of the Western Cape indicates that almost $30 \%$ of individuals live below the poverty line in "absolute poverty" (SerumagaZake, Kotze \& Madsen, 2005:143). These statistics give a realistic indication of the context within which the research was conducted. The families who participated in the research provided descriptive accounts of their own experiences of poverty:

"We used to go to school with no shoes on our feet, no jersey, no food to eat." $(P E)$

"I was living on the streets with the kids ... when the birds come down to eat then you catch them; I killed them and then the kids helped me pull off the feathers and then you boil them." (PC)

"[I have] been staying here for 11 years. No water. Without sanitation. No electricity. It is sometimes a risk with the candle use. No toilet." (PG)

Document analyses (i.e. the case files) of participants indicated that there is also a heavy reliance on government grants to sustain the family (child support, foster care and pension grants). This research indicated that the participant families have lived in poverty circumstances for many generations and that the risk factors identified have been transmitted to each generation. It seems clear that families living in post-apartheid South Africa are still living in poverty-stricken circumstances similar to those of the previous generations of their grandparents, indicating a serious gap in government attempts to address social inequalities (Morkel, 2011:486-489). It was also evident that the living circumstances of the poor meant that the family system struggles to meet its basic needs for food, water and electricity. Barrett (in World Bank, 2008:6) acknowledged that the need to maintain a steady level of income to meet basic needs is the optimal strategy of such poor families. Many of the participants indicated that employment would have enabled the family to break free of the cycle of poverty (Theme 6).

\section{Theme 2: Trauma, loss and bereavement}

Through the data-collection strategies employed (i.e. lifeline, ecomap, loss and gain spirals) it was found that many of the participants presented with loss, trauma and bereavement in their lives:

"We had seven people die in seven years." (PA)

"My second baby passed away in a car accident. [She was] 6 years old." (PG)

(Participant starts to cry). "He would beat my mother. And we suffered a lot. One day he stabbed her with a knife, I grabbed the blade, and my whole finger was off." (PF)

Since the 1990s South Africa has had one of the highest murder rates in the world. In 2006 it was estimated that there were 50 murders per day in South Africa (Kaminer \& Eagle, 2010:13-14). Four of the seven participants interviewed had experienced a murder in the family: 
"My father got murdered by the train station - they stabbed him." (PG)

"My sister's son, he was retarded; he got burnt out from the shack. The police said this was murder." (PA)

"[My] third [husband] died. That was a tough time that I went through. I had to go under psychiatric care. He was shot ... he was murdered." (PE)

Harvey (2002:10) states that bereavement is worsened when there is a loss of a significant person to whom the individual would usually turn to for help, as was the case with PF, who missed the support of her mother. PC also mentioned that her grandmother would have supported her in many practical ways if she was still alive. Kaminer and Eagle (2010:45) indicate that survivors of trauma typically have difficulty in controlling their feelings, are unable to self-soothe and struggle to get comfort from others. It could be that unresolved traumas, loss and bereavement could utilise energy in participants which could negatively affect their general functioning. This is in line with Harvey (2002:15) and Rando (1993), who recognise that "dealing with loss events may lead to secondary losses of energy and resources".

The transformative power of loss (Harvey, 2002:9) seemed to be mainly absent from the participants as they generally could not report deeper insight and meaning from their loss. It is of concern that the emotional trauma suffered by the participants has apparently rendered them unable to achieve a sense of wholeness and fulfilment in their lives. One participant (PF) indicated that the research interview was the first opportunity in her 63 years that she ever had to talk about her life history. She expressed a sense of relief by saying that it felt as if a burden lifted. It is worrying that this participant, who has a long-term welfare involvement, never had the opportunity to talk to a professional person about her traumatic life experiences.

It is clear from the literature and participant responses that these multi-problem poor families are dealing with loss, trauma and bereavement. The concern is how they have, or rather have not, been able to integrate this loss into deeper insights and finding meaning for their lives.

\section{Theme 3: Previous generation family}

Theme 1 indicates that the participant families are living in poverty; as such, they have few resources available to meet their basic needs. Pryor and Rodgers (2001:142) note a correlation between poverty and divorce in families, which was found to be true in this research as well. Harvey (2002:62) recognises that divorce is accompanied by further loss of resources (energy, income), which places these families at additional risk. Pryor and Rodgers (2001:167) state that reconstituted/blended families involve the rearrangement of households, which has the potential to disrupt family systems. Research studies also indicate that marital tension, conflict and parental separation have negative effects on children's development, academic achievement, wellbeing, social and interpersonal relationships (Grych, 1998; Hetherington \& Stanley-Hagan, 1999; Pryor \& Rodgers, 2001; Walper \& Beckh, 2006). The participants presented information on their complicated family situations as follows: 
You are one of seven, tell me about growing up?

"It was tough, it was not nice. I think that is why I am still battling the way I am today. There was no support, no love, no absolutely nothing." (PE)

"My mother was a drinker, my step father was a drinker ... that's my real father (points to genogram), he was also a drinker. They divorced through the drinking and my mother had a relationship with my stepfather; a 'skelm' affair." (PC)

Most of the participants interviewed come from earlier generations of broken families, where their parents divorced as a result of extra-marital affairs and marital dissatisfaction. High rates of blended families were also found amongst participants. Data collected from participants and document analysis (i.e. of the case files) indicated that while the participants came from broken and blended families themselves, many of them and even their children are also divorced or have experienced the same type of blended families as the grandparents did. Amato (in Clarke-Stewart \& Dunn, 2006:179) states that studies indicate that parental divorce is associated with problematic outcomes in adulthood, including experiencing divorce themselves and conflict in their own marriages. The literature and data gathered from research participants indicates that there is an intergenerational transmission of divorce and marital dissatisfaction in multiproblem poor families.

\section{Theme 4: Intergenerational risk factors}

The research found evidence of risk factors occurring in earlier and current generations.

\section{Substance abuse}

As indicated in theme 2 above, all of the participants have unresolved loss, trauma and bereavement issues that they struggled to deal with. Zuckerman (1994) suggests that individuals abuse substances in order to block out emotional trauma.

"It was heartbroken, it were hurtful, nerve wrecking, stressful. Then my brothers started drinking because of my father, and the family split apart." (PA)

Fisher and Harrison (1997:223-224) and Straussner and Fewell (2010) note that adult children of alcoholics may become substance abusers themselves and tend to choose partners who are also substance abusers. This was found to be true for the participants as well:

"My dad was a drinker. (My husband) was an alcoholic too, and a drug addict." $(P E)$

"My youngest child ... he is also on drugs ... she sold her teeth for TIK. ” (PC)

Participant G's family appeared to have intergenerational issues of substance abuse as PG's mother had a drinking problem, PG started to smoke and drink when she was about 22/23 years old, the father of PG's children had a substance-abuse problem, and her son (14 years) started experimenting with drugs. Participant A reflected on the detrimental effects of substance abuse on their family, such as family fights. James and Gilliland (2001) indicate that children exposed to substance abuse in the family 
experience deleterious effects, including feelings of worthlessness, self-blame, withdrawal and poor academic performance.

Strausser and Fewell (2010) and Gruber and Taylor (2006) indicate that there is a high correlation between parents that abuse substances and domestic violence, as well as between dysfunctional parenting and substance abuse. There is an increased risk of child abuse and neglect amongst substance-abusing parents.

Participant D reported that her husband was never home, and that when he was home he was abusive and rude. She said that he died when he was 36 years old of alcoholismrelated complications. She indicated a sense of relief when he passed away. Document analysis of PD's family indicated that PD's daughter is abusing substances and is unemployed, and that the daughter's own child is currently in foster care.

It is clear is that there is an association between substance abuse and experiences of violence (domestic violence and child abuse). Data gathered from participants showed that they experienced parental substance abuse and domestic violence, and most of the participants were subjected to child abuse or neglect, as is supported by the literature (Gruber \& Taylor, 2006; James \& Gilliland, 2001; Strausser \& Fewell, 2010).

\section{Domestic violence}

Kaminer and Eagle (2010:17) report that in 2002 the Western Cape presented with the highest rates of gender-based violence in South Africa. This research corresponded with the literature as it indicated that each of the participants experienced some form of domestic violence (from their parents and their partners). Having being subjected to parental domestic violence, participants seemed to choose partners who were also violent towards them. Mattingly and Dugan (in Keeling \& Mason, 2008:197) support this in their comment that partner violence is not a one-time thing for women; even when a violent relationship ends, that previously victimised women often becomes involved in another abusive relationship. As indicated in the previous section, there was a strong link between substance abuse and domestic violence. Flanzer (2000) argues that alcohol abuse is the prominent risk factor contributing to domestic violence, because alcohol lowers the abusers' inhibitions against becoming violent (in Roleff, 2000:54-55). This research supports this finding in that it indicated a correlation between those who abuse alcohol and those who are abusive towards others:

"When he [father] was coming home [after drinking with friends], he used to shout at her [mother] and he pushed her, and she cut her whole head open. I screamed. I still had my younger sister on my arm. And I put her down, and I grabbed towels to stop the blood. I screamed for our neighbour and we called the ambulance - but he ran away, and the police was after him. He would hurt my mother, and he was abusive to us. " (PF)

James and Gilliland (2001) and Little (in Stith, Williams \& Rosen,1990) recognise the denial of the seriousness of abuse, as demonstrated by participants $F$ and $\mathrm{G}$ below: 
"My mother drank, but not my father. You know how it is, some fighting and arguing, but nothing bad." (PG)

"Even if my father used to beat my mother, he was a loving father." (PF)

Victims of abuse often deny the seriousness of their experiences and express ambivalent feelings about the abuse in an attempt to cope. Only one participant seemed to be an example of "breaking the mould" in her marriage after having being exposed to the domestic violence and substance abuse of her own parents.

"38 years we have been married. We got our ups and downs, but he never lifted his hand to me. Because I told him, I came out of an abusive home, and I don't want to step into an abusive home." (PF)

Field and systems theory (Härkönen, 2007; Minuchin et al., 2007) shows that the individual cannot exist in isolation. These theories indicate that domestic violence is a result of interacting factors within the system: poverty, substance abuse, marital dissatisfaction, stress and unemployment.

The negative impact on children of parental domestic violence has been documented by research (Emery, 1999; Rossman, Hughes, \& Rosenberg, 2000:91) and indicates that "witnessing violence is a negative and often traumatic experience for children" (Rossman et al., 2000:15). Zuckerman (1994:53) says that the negative impact on children of domestic violence is that there is poorer functioning at school. This is identified in the subthemes below of teenage pregnancy and early school dropout. Kemp (1998) states that experiences of abuse and neglect also interrupt the attainment of needs, as discussed above.

\section{Child abuse/neglect/statutory intervention}

Research by Algood, Hong, Gourdine and Williams (2011), Jaffee, Caspi, Moffitt, PoloTomás and Taylor (2007), and Fujira and Yamaki (2000) indicates that children who live in poverty are at greater risk of being abused than children who do not live in poverty. It is already clear that the participant families come from deprived circumstances (Theme 1); and the literature indicates that such families are at risk of child abuse and neglect, which was found to be the case in this research. This again resonates with systems theory that child abuse and neglect are the result of an interaction of the parts within the field (Kemp, 1998:16). In line with Bronfenbrenner's conceptualisation of the macro system (Härkönen, 2007; Kemp (1998:86-87) states that broader systems of social factors (unemployment, stress and poverty) directly influence the subsequent abuse of children by their parents.

Masten and Shaffer (in Clarke-Stewart \& Dunn, 2006:13) show that child abuse and neglect by the parent has a far more detrimental effect on the child than abuse by strangers. They also view such disturbances to the family system as having ruinous outcomes for the child's development. Longitudinal studies have shown that abused and neglected children exhibit a number of problems, including school failure and substance use (Cicchetti \& Manly, 2001; Widom \& Maxfield, 2001). Participant D indicated that her husband abused their children and this lead to the removal of the children: 
"He would hit the children so I took them to the welfare, and I told them to please put my children in the Catholic home." (PD)

Theme 3 indicated that all of the participants come from broken homes and it was also found that many of them experienced some form of child abuse or neglect. This finding appears to be supported by the theory as Pryor and Rodgers (2001:151) indicate that "children of separated families are more likely to experience abuse and neglect than children who do not experience family transitions".

Data gathered from participants indicated that over half of the families had been affected by sexual abuse, and that the children affected by it were often statutorily removed from the family. Document analysis (of the case files) showed that PD's child was raped, and the child born of that rape, PD's grandchild, was sodomised. It was also found that PA's family is currently dealing with the effects of child sexual abuse, which included the child being placed in a children's home. Participant F described her experience when she and her siblings were placed in different children's homes because of parental neglect and physical abuse. Although, she found it a negative experience in general, she expressed relief that she was free from the abuse and fear she had experienced at home. Document analysis also indicated that PC's children were removed from her care because of her own substance abuse and neglect of her children, and that PC's grandchildren were also removed and placed in foster care.

Participant E described how she and her siblings were removed to a place of safety and how they were eventually separated. Document analysis revealed that PE's own children have been removed from her care and are currently placed in a children's home. It became evident in the research that there is a continuous cycle of removing children and placing them in alternative care as a means to deal with the various problems presented in these multi-problem poor families. In view of the family's perpetuating history, this appears to have been an ineffective form of intervention.

The research further indicated that some of the participants experienced emotional abuse. Emotional abuse is described by Wiehe (1998:17-18) as "psychological maltreatment whereby an adult attacks a child's self-esteem and social competence. This form of abuse is seen in comments made with the intent of ridiculing and belittling a child". Participant C described how she was the target of abuse when her mother was drunk (being told "You are stupid"). Participant E described her mother's attitude of hate towards her and linked it to her problematic relationships with her own children and husbands.

The intergenerational theory of abuse suggests that abused children become abusive parents themselves (Wiehe, 1998). The research revealed that it was most likely that the participants who were abused as children then later lacked parenting skills as adults and were therefore not able to improve their parenting of their own children.

By comparing abused and non-abused children, Cerezo and Frias (1994) found that severe academic problems were prominent in abused children. These problems were so severe that there was a high risk of school dropout (subtheme discussed below). 


\section{Teenage pregnancy}

As far back as 1998 it was found that in South Africa 35\% of all teenagers had been pregnant before the age of 19 years (National Population Unit, 2000). Clearly teenage pregnancy is a problem in South Africa and a number of generations have experienced teen pregnancies, as is evident from this research.

"I was 17 when I had my first child. My granny also had her first child when she was $14 / 16$ years old." (PC)

"My first child was born when I was 18 years old." (PD)

Participant B's mother was 17 years old when she (PB) was born and her mother's sister had her first baby when she was 13 years old. Participant C's history shows patterning in terms of teenage parenthood:

"My youngest child ... 16 she had her first child. My oldest son got a child when he was 16 years ... And now his child she is 16 years old, and she has a child." $(P C)$

Pregnancy limits the capacity of teenage mothers to return to school and complete their education, thus also hindering future employment and economic opportunities (Gray, Spurway \& McClutchey, 2001:648; McLeod, 2011:62; Sousa \& Eusebio (2005:354). Bezuidenhout (1998) recognises the burden that teenage pregnancies place on government, as these young parents typically fail to complete school and rely on government child-support grants.

Most of the current research is focused on teenage mothers and little attention has been given to teenage fathers. Negative consequences of fatherhood for adolescent boys include increased poverty and welfare dependency (Mollborn, 2006; Swartz \& Bhana, 2009:3). Gray et al. (2001) indicate that mothers at high risk in terms of parenting difficulties are those with limited knowledge of pregnancy, birth and care of infants. Participant C's description of her teenage pregnancy indicates the limited knowledge she had of pregnancy and the need for better sex education:

"I was 17 when I had my first child. I wanted to cut my stomach open to take this child out. I just didn't know how it could come out." (PC)

Two of the participants who had been through teenage pregnancies put their children up for adoption. There are obvious emotional implications to having a child adopted. McLeod (2011) suggests that the young teenage mother is psychologically immature and unable to comprehend the long-term consequences of her actions. These adoptions are evidently a further indication of the loss, trauma and bereavement that these participants have experienced. The first mother (PC) still has unresolved issues regarding her adopted child. She sometimes referred to her during the interview as not being her child, but rather her sister. As many participants left school because they were pregnant, the cycle of poverty and welfare dependency is evident in these families' lives across each generation. 


\section{Early school dropout and poor academic performance}

The Social Profile of South Africa 2002-2009 (STATSSA, 2009) indicated that a large proportion of children fail to pass Grade 7 by the age of 15 years. Children cited reasons for early school dropout as being teen pregnancy, education not being seen as "useful", lack of money and poor academic performance. These grim statistics were evident in this research as well.

During the participant interviews it was found that PA and PD only completed Grade 7. All participant D's children dropped out before high school, with the youngest not progressing further than Grade 4. Participants E and F completed Grade 10, and Participant G left school in Grade 11 as she felt out of place in school after her friends had left school to start working. The research found that none of the participants had completed Matric and that many of the family members did not pass Grade 8. This links with Crouch's (2005) concern about "disappearing school children" as $40 \%$ of children do not reach Grade 12.

Kiernan and Mensah (2009:570) indicate that the "long hand of childhood poverty persists into adulthood in terms of lower educational attainment", linking poverty and poor academic achievement (Kiernan \& Mensah, 2009:575). A major problem identified in this research in the document analysis of PA, PB, PC, and PD is that the younger generations of children struggle academically at school and the grandparents at home cannot assist them with their school work as they did not attain higher levels of education. There are also concerns about the expectations placed on these families by the schools with regard to school projects and printed assignments. These multi-problem poor families come from deprived homes and often cannot meet the school's requirements and expectations. The children seem to be despondent and hopeless in this situation, and eventually drop out of school. Kannemeyer (2008:9-10) supports this finding in her observations that the capacity of current parents to assist their children is a function of the education they themselves obtained, and that "there is a problem of parents being unable to provide educational assistance and compensate for the shortfalls in the public schooling system".

Document analysis also found that PC's children and foster children had and were attending a special school for children with learning disabilities. Involvement in special schools appeared to be common to most of the participants' families.

It is evident from the literature and participant interviews that most of the family members in these multi-problem poor families have not completed their schooling. It seems likely that this limited educational achievement has also inhibited their capacity to escape the cycle of poverty. It appears that there is more need for skill-based school systems, where education is focused on trade and artisanal skills (hairdress ing, plumber, etc.) for these multi-problem families.

\section{Loss of resources}

Problems cause a certain level of stress for the individual and family trying to cope with them. However, it may be that multi-problem poor families are at greater risk in trying to manage these stressful situations as a result of their limited resources and higher 
exposure to risk factors. Hobfoll (1998:28) says that stressful circumstances are those that "remove or threaten obtainment and maintenance of survival of the self and family". According to conservation of resources (COR) theory, "stress is predicted to occur as a result of circumstances that represent a threat" or loss to resources (Hobfoll, 1998:4546). Resources are inextricably linked to survival and include object or material resources (i.e. house, car, clothing), condition resources or psychosocial resources (i.e. family membership and employment), personal resources (i.e. self-esteem, social skills, job skills) and energy resources (i.e. food, money, credit, knowledge) (Hobfoll, 1998:54; Hobfoll, Mancini, Hall, Canetti \& Bonanno, 2011:1402). The loss of resources in a family system is experienced like a downward spiral of losses which leaves the family system feeling hopeless and out of control. This research found that participating families presented with a number of losses of resources: loss of object resources (living on the streets with children, going to school without school shoes); loss of energy resources (not having money or food, living in a shack); loss of condition resources (job loss); loss of personal resources (loss, trauma and bereavement, deteriorated familial relationships, and family violence.

Document analysis also indicated that some participants were unresponsive to the assistance offered by social workers and they appeared to lack any motivation to improve their circumstances. Various authors refer to this as the multi-problem poor family's resistance to intervention (Sousa et al., 2007:54; Sharlin \& Shamia, 2000:5). It is possible that these families might have felt that the risk of accepting assistance from social workers was too high and could lead to resource loss in other areas, i.e. statutory removal of their children.

Pryor and Rodgers (2001:140) note that "multiple risk factors have a cumulative or synergistic effect on children and families", resulting in an even greater impact than would separate or single-risk factors. This indicates that a multitude of risk factors has a detrimental effect on the individual and family system - as each of the participants in this research has experienced (Pryor \& Rodgers, 2001).

\section{Theme 5: A new presenting risk factor in current generation}

The empirical investigation found that while most of the risk factors could be seen across the generations, there was one risk factor that appeared to only present itself in the current generation of parents and children, and this relates to the aspect of absent parents to be presented next.

Bradshaw, Stimson, Skinner and Williams (1999:2) state that the number of absent fathers increased rapidly in the 1980s and especially in the 1990s, and it is still increasing today. Absent fathers in society is not a new phenomenon (Dobson, 2002; Kimani, Kombo \& University, 2010; Morrell \& Richter, 2006). The Sunday Independent Newspaper (21 June 2011) stated that according to the Human Sciences Research Council, over $51 \%$ of children in South Africa are growing up without a father (not dead) (Van Eeden, 2011). Kimani et al. (2010:19) find that poverty accounted for 52\% of the factors contributing to absent fathers. They further report that in South Africa $71 \%$ 
of high school dropouts come from fatherless homes, indicating the link between early school dropout and absent fathers, which is also evident in this research.

Participant A reflected on the absence of the great-grandchildren's father and stated that she and her mother cared for the children. Participant $\mathrm{C}$ was pregnant when the father of her child got a life sentence and went to prison. Another participant (PF) raised her granddaughter. Document analysis of PA, PB, PC, PD, and PG's files indicated that a few of the fathers of the current generation of children were denying paternity of the children.

Contact made by social workers with the children revealed that the children miss their absent parents and that they want contact with them. It seems that this accounts for feelings of loss and abandonment in these children.

Literature sources (Bradshaw et al., 1999; Dobson, 2002; Kimani et al., 2010; Morrell \& Richter, 2006; Van Eeden, 2011) acknowledge the absence of fathers, but this research found that there were many mothers who were also absent from their children's lives. While earlier generations suffered parental substance abuse and domestic violence, it appears that current generations are dealing with a missing generation of parents. Further research on the effect of this missing generation of parents on children is warranted.

\section{Theme 6: Protective factors}

Sousa and Eusebio (2005:356) recognise the value of protective factors as "research has shown that services for multi-problem poor families usually contribute to the disorganisation in these individuals and families. Because services are often fragmented and uncoordinated, they are less effective; and because interventions are focused on individuals and problems, they do not tap the healing possibilities that reside within families and communities". This is supported by Minuchin et al. (2007:24) in their argument that while multi-problem families are consumed by concerns about drugs, neglectful parents and violence, the strengths within these families (loyalty and affection shown between family members) are often overlooked. The protective factors are outlined below

\section{Support from family, friends, and the community}

Sousa (2005:163-164) and Masten and Coatsworth (in Rossman et al., 2000:101) found that informal personal networks of strong family ties, friends and neighbours provide a sound support system against risk factors in multi-problem poor families.

Multi-problem poor families have usually been characterised in terms of isolation, detachment and exclusion from family and the broader community (Eamon, 2001; Sousa, 2005:166). However, the participants' responses indicated that the opposite is true in that the family maintained a sense of togetherness and supported one another despite dire circumstances. Jaffee et al. (2007) support these findings and refer to family relationships and community support systems as promoters of resilience in dealing with risk factors.

Participants referred to the value of social support. Participant A mentioned that they were a close-knit family and that the older generation felt responsible towards and cared 
for the grandchildren and great-grandchildren. Participant G mentioned gains in the form of favours and odd jobs, and PF mentioned the Women's Forum, who helped her build personal resources in terms of assertiveness.

It is clear that reliance on other family and friends for support was a major protective factor in combating the struggles of hardship and poverty. Ubuntu is a South African term referring to the idea of being human, that "I am a person through other persons" (Broodryk, 2007:39). It encompasses the values of sharing, being helpful, compassion and caring for others. The notion of ubuntu is recognised by Sousa (2005:177) as a saving grace for multi-problem poor families in her final remarks that "a person's problems are not his or hers alone. This revitalises the sense of community and provides discursive options that centralize our relational engagement". The participants illustrated this in the following examples:

"People come here and say I haven't eaten in three days, then I will share with them ... we help each other." (PC)

"There was a nurse there at Woodstock hospital and she said "I will help you". She gave me a form and I started to work there. I put the kids in the crèche and with my first pay, I got a room. And then we start to live better." (PC)

These examples indicate how a downward spiral of resource loss can be turned around into a spiral of resource gain.

Participant C's account of how they find food indicates creativity and skill:

"If there's nothing in the house then I tell them, there's the pot, it's empty. So it's me, and five other people. We must make a way, we can't steal; we must do something. My son goes and washes a car ... the foster child will go to the shop and will get food on the book ... like a packet of Vienna's ... he will go find beer bottles in the community and will take it back and get money to buy potatoes ... I will do the lady's washing in my machine; she will pay me in rice ... We bring it all together and can make food. " (PC)

The research indicated that the family members do support each other and that there is a strong sense of community that enables the family system to survive the negative poverty-stricken circumstances.

\section{Religious belief system}

Census 2001 (STATSSA, 2001) indicates that $79.8 \%$ of the South African population are Christian. This research found that a belief in God was another strong protective factor that most of the participants recognised as enabling them to cope. Participants A, $\mathrm{E}$ and $\mathrm{C}$ spoke about the value of being involved in a church and the value of prayer. PG related the positive influence of her grandmother, who was a churchgoer.

\section{Resource gain}

As discussed earlier, the families interviewed portrayed a downward spiral of losses that they had experienced in the course of their lives. The research was also interested in 
identifying the protective factors of these families. Hence, upward spirals of resource gains were identified.

Gains in object resources - Only one participant (PE) indicated that housing would make a difference to the family's experiences of poverty. The benefits of adequate and sufficient housing for these multi-problem families could include stability, basic amenities and less overcrowding.

Gains in energy resources - Participants recognised the family's need for money.

Gains in condition resources - The research indicated that only two individual members within two families managed to complete school and obtain employment.

"I am proud of my second eldest child; he actually finished school through the post. Then he got a job, now he is working at that new hospital as a pharmacist." $(P E)$

"She got Matric in the post. She worked as a girl Friday. She is overseas today in New York." (PF)

In both of the above-mentioned cases the children did not grow up with their parents (the participants interviewed), but rather with other family members. Interestingly, the only breaks from poverty in these families came from individuals who did not grow up with their families of origin.

Sustainable employment was an obvious condition resource with positive effects on object, energy and personal resource levels. It added income, food, shelter, feelings of self-worth and a sense of security.

Other condition resources that were considered to be protective factors included the police, social workers, boarding schools, homes for pregnant teenagers, the council and lawyers.

Document analysis indicated that all the participant families were obtaining support from the social workers by way of foster-parent support groups, awareness programmes, holiday programmes and parenting skills workshops. The Red Cross Children's Hospital Child and Adolescent Unit and Legal Aid were organisations providing further assistance and support to families. However, even though these resources were utilised, this did not succeed in breaking the cycle of poverty.

Gains in personal resources - A positive attitude and a belief in oneself, religious belief as well as the ability to problem solve stood out as personal resources that assisted families in coping with multiple problems.

It is clear that condition resources of community support, job opportunities and employment as well as personal resources and problem-solving skills are the major protective factors for these multi-problem poor families.

Theme 6 identified that religious beliefs, support systems and resource gains have enabled multi-problem poor families to survive. However, it is also clear that these families have remained in the cycles of poverty and welfare dependency despite having 
these protective factors and the resources available to them. It seems that intervention with these families needs to make use of these strengths in addressing the risk factors presented in the family system.

\section{FINDINGS}

The following findings emerged from the data collected from the participants.

- The dominant intergenerational risk factors in multi-problem poor families include parental substance abuse, domestic violence, teenage pregnancy and early school dropout.

- In the past alcohol abuse was dominant. In today's current family systems drug abuse appears to be causing problems for families.

- The intervention response of welfare systems in multi-problem families has been the statutory removal of children. Since multi-problem families keep battling with the same problems in each new generation, this intervention appears to be ineffective.

- Exposure to parental domestic violence and marital dissatisfaction seems to lead to the same issues being present in the next generation. This supports the theory that these are learnt behaviours that make divorce and violence seem normal.

- Each of these families has trauma, loss and bereavement issues that have not been dealt with in a meaningful way. There is a lack of resources available to deal with the loss and grief in multi-problem poor families.

- The grandparents and even some great-grandparents have taken responsibility for the grandchildren because of the missing parent generation. Interestingly, with the children in these families being in substitute care, it seems as if young children are currently also evolving into a missing generation.

- The major protective factors across generations have been the sense of community and support that have been offered by family, friends and the community.

- Personal resources such as a belief in oneself and problem-solving abilities are also protective factors which seem to have a significant impact on the survival of these multi-problem poor families.

- Families have identified employment and job opportunities as the keys to improving their lives and escaping the cycle of poverty.

\section{RECOMMENDATIONS}

In view of the above, several recommendations are made.

- Further research needs to be conducted on the reasons for the heavy reliance on government grants and the major lack of employment among these multi-problem families. Families need to be interviewed on their job-seeking behaviour to determine whether their lack of employment, dependence on government grants, and subsequent poverty are due to inadequate internal sources, such as their own lack of motivation to find a job, or due to external sources, such as a lack of jobs available in South Africa, or a combination of internal and external reasons. 
- The majority of the teenage pregnancies involved girls between the ages of 13 and 17. Further research is required to determine the level of understanding of learners in primary and high schools of basic human biology, sexual reproduction, safe sex practices and pregnancy prevention. Based on this research, early intervention programmes need to be implemented in schools to address sex education.

- In support of findings by Kaminer and Eagle (2010:53), it is recommended that further research be conducted on the loss, trauma and bereavement issues of multiproblem poor families. While therapeutic services are available to abused children, there appears to be a lack of therapeutic intervention and support for adults. Research can be conducted to determine the level of resources available to such families to deal effectively with bereavement, loss and grief, when so much of their energy resources are utilised to survive day to day.

- Intervention programmes need to be targeted at parental substance abuse. It appears that parents lack awareness of the effects that their substance abuse has on the family because of the very nature of denial in substance abusers. Intervention programmes can be implemented to raise parents' awareness of the effects that their substance abuse has on their children, the family and the community.

- Research is needed to explore the long-term effects of the current absent-parent generation. Longitudinal studies are needed to determine what the impact will be on the lives of those children whose parents are absent.

- Extracurricular support programmes need to be implemented to assist multi-problem poor families to enhance academic performance. It is clear that these families come from generations of early school dropouts. Hence, there is a lack of educational support at home. Homework supervision, extra lessons and curricula support programmes are desperately needed to provide support to the current generation of children who are struggling academically. This seems imperative in order to break the cycle of poverty. The impact of one child being able to finish school and obtain steady employment could dramatically assist these multi-problem families to break out of the cycle of poverty and deprivation. Programmes such as the Mondesa Youth Opportunities Programme in Swakopmund (Gouws, 2012) can be used for guidelines.

- The protective factors identified by families are community support systems. In agreement with Rodrigo, Máiquez, Correa, Martin and Rodriguez (2006), and MacLeod and Nelson (2000), future interventions should be aimed at strengthening these community network and support systems. Such programmes could include home-visiting programmes to high-risk families (e.g. teenage mothers), community forums, community-based small support groups and mentorship programmes for youths.

- Should programmes such as these be implemented, it is recommended that longitudinal studies be undertaken to evaluate the effectiveness of such interventions in terms of these families. 


\section{CONCLUSION}

In conclusion, this empirical investigation explored the dynamics of multi-problem families, focusing on the risk factors that have sustained the families' perpetuating cycle of poverty and deprivation. Protective factors were also identified which have enabled these families to survive their day-to-day struggles. It is clear that future interventions aimed at these families need to address parental substance abuse and domestic violence, while other programs need to target teenage pregnancy and early school dropout.

\section{REFERENCES}

ALGOOD, C.L., HONG, J.S., GOURDINE, R.M. \& WILLIAMS, A.B. 2011. Maltreatment of children with developmental disabilities: an ecological systems analysis. Child and Youth Services Review, 33:1142-1148.

AMATO, P.R. 2006. Marital discord, divorce, and children's wellbeing: results from a 20-year longitudinal study over two generations. In: CLARKE-STEWART, A. \& DUNN, J. (eds) Families count: effects on child and adolescent development. New York: Cambridge University Press, 179-202.

BARRETT, C. 2004. Rural poverty dynamics: Development policy implications. Agricultural Economics, 32(1):43-58. In: THE WORLD BANK 2008. Poverty and the environment: understanding linkages at the household level. Washington.

BEZUIDENHOUT, F.J. 1998. A reader on selected social issues $\left(2^{\text {nd }}\right.$ ed $)$. Pretoria: Van Schaik Publishers.

BRADSHAW, J., STIMSON, C., SKINNER, C. \& WILLIAMS, J. 1999. Absent fathers? London: Routledge.

BRAUN, V. \& CLARKE, V. 2006. Using thematic analysis in psychology. Qualitative Research in Psychology, 3:77-101.

BROODRYK, J. 2007. Understanding South Africa: the Ubuntu was of living. South Africa: Ubuntu School of Philosophy.

CEREZO, M.A. \& FRIAS, D. 1994. Emotional and cognitive adjustment in abused children. Child Abuse \& Neglect, 18:923-932.

CICCHETTI, D. \& MANLY, J.T. 2001. Operationalizing child maltreatment: Developmental processes and outcomes. Development and Psychopathology, 13(4).

CLARKE-STEWART, A. \& DUNN, J. (eds) 2006. Families count: effects on child and adolescent development. New York: Cambridge University Press.

CROUCH, L. 2005. Disappearing school children or data misunderstandings? [Online] Available: http://www.education.gov.za/LinkClick.aspx?fileticket=eBrQkXYM Ilo\%3d\&tabid=137\&mid=433 [Accessed: 07/09/2011].

DOBSON, J. 2002. Bringing up boys. Cape Town: Paarl Print.

EAMON, M.K. 2001. The effects of poverty on children's socio-emotional development: An ecological systems analysis. Social Work, 46:256-266. 
EMERY, R.E. 1999. Marriage, divorce and children's adjustment $\left(2^{\text {nd }}\right.$ ed). Beverly Hills CA: Sage Publications.

FISHER, G.L. \& HARRISON, T.C. 1997. Substance abuse: information for school counsellors, social workers, therapists, and counsellors. Massachusetts: Allyn \& Bacon.

FLANZER, J.P. 2000. Alcohol abuse causes domestic violence. In: ROLEFF, T.L. Domestic violence: opposing viewpoints. California: Greenhaven Press, 54-62.

FOUCHÉ, C.B. \& DELPORT, C.S.L. 2011. Introduction to the research process. In: DE VOS, A.S., STRYDOM, H., FOUCHÉ, C.B. \& DELPORT, C.S.L. (eds) Research at grass roots: for the social sciences and human service professions $\left(4^{\text {th }}\right.$ ed). Pretoria: Van Schaik Publishers, 61-76.

FOUCHÉ, C.B. \& SCHURINK, W. 2011. Qualitative research designs. In: DE VOS, A.S.; STRYDOM, H.; FOUCHÉ, C.B. \& DELPORT, C.S.L. (eds). Research at grass roots: for the social sciences and human service professions $\left(4^{\text {th }} \mathrm{ed}\right)$. Pretoria: Van Schaik Publishers, 307-327.

FUJIRA, G.T. \& YAMAKI, K. 2000. Trends in demography of childhood poverty and disability. Exceptional Child, 66:187-199.

GOLDENBERG, I. \& GOLDENBERG, H. 2004. Family therapy: an overview $\left(6^{\text {th }}\right.$ ed). USA: Thomson.

GOUWS, L. 2012. The experiences of alumni adolescents on the contribution of the Mondesa Youth Opportunities Programme. Potchefstroom: North-West University. (MA-thesis)

GRAY, J., SPURWAY, P. \& McCLUTCHEY, M. 2001. Lay therapy with families at risk for parenting difficulties: the Kempe Community Caring Program. Child Abuse \& Neglect, 25:641-655.

GRUBER, K.J. \& TAYLOR, M.F. 2006. A family perspective for substance abuse: Implications from the literature. Journal of Social Work Practice in the Addictions, 6(1/2):1-29.

GRYCH, J.H. 1998. Children's appraisals of interparental conflict: situational and contextual influences. Journal of Family Psychology, 12:437-453.

HÄRKÖNEN, U. 2007. The Bronfenbrenner ecological systems theory of human development. In: Scientific Articles of $\mathrm{V}$ International Conference: PERSON.COLOR.NATURE.MUSIC. Daugavpils University, Saule: Latvia.

HARVEY, J.H. 2002. Perspectives on loss and trauma: assaults on the self. USA: Sage Publications.

HETHERINGTON, E.M. \& STANLEY-HAGAN, M. 1999. The adjustment of children with divorced parents: a risk and resiliency perspective. Journal of Child Psychology and Psychiatry, 40:129-140. 
HOBFOLL, S.E. 1998. Stress, culture and community: the psychology and philosophy of stress. New York: Plenum Press.

HOBFOLL, S.E., MANCINI, A.D., HALL, B.J., CANETTI, D. \& BONANNO, G.A. 2011. The limits of resilience. Distress following chronic political violence among Palestinians. Social Science \& Medicine, 72:1400-1408.

HOLLOWAY, I. \& WHEELER, S. 1998. Qualitative research for nurses. Great Britain: MPG Books.

JAFFEE, S.R., CASPI, A., MOFFITT, T.E., POLO-TOMÁS, M. \& TAYLOR, A. 2007. Individual, family and neighbourhood factors distinguish resilient from non-resilient maltreated children: a cumulative stressors model. Child Abuse \& Neglect, 31(3):231253.

JAMES, R.K. \& GILLILAND, B.E. 2001. Crisis intervention strategies ( $4^{\text {th }}$ ed). USA: Brooks \& Cole.

JORDAN, B. 1978. Poor parents: social policy and the 'cycle of deprivation'. London: Routledge and Kegan Paul Publishers.

KAMINER, D. \& EAGLE, G. 2010. Traumatic stress in South Africa. South Africa: Wits University Press.

KANNEMEYER, C. 2008. School dropout in the Western Cape: the role of prior school progress, ability, pregnancy and family background. Cape Town: UCT (MA thesis).

KEELING, J. \& MASON, T. (eds) 2008. Domestic violence: a multi-professional approach for healthcare practitioners. England: Open University Press.

KEMP, A. 1998. Abuse in the family: an introduction. USA: Brooks \& Cole.

KIERNAN, K.E. \& MENSAH, F.K. 2009. Poverty, maternal depression, family status and children's cognitive and behavioural development in early childhood: a longitudinal study. Journal of Social Policy, 38:569-588.

KIMANI, E.; KOMBO, K. \& UNIVERSITY, K. 2010. Challenges facing nuclear families with absent fathers in Gatundu North District, Central Kenya. The African Symposium, 10(2):11-25.

LEEDY, P.D. \& ORMROD, J.E. 2005. Practical research: planning and design. New York: Pearson Merrill Prentice Hall.

LITTLE, L.F. 1990. Gestalt therapy with females involved in intimate violence. In: STITH, S.M., WILLIAMS, M.B. \& ROSEN, K. Violence hits home: comprehensive treatment approaches to domestic violence. New York: Springer Publishing Company, 47-65.

MALINDI, M. \& THERON, L. 2011. Drawing on strengths: images of ecological contributions to male street youth resilience. In: THERON, L., MITCHELL, C., SMITH, A. \& STUART, J. Picturing research: drawing as visual methodology. Netherlands: Sense Publishers, 105-117. 
MASTEN, A.S. \& SHAFFER, A. 2006. How families matter in child development: reflections from research on risk and resilience. In: CLARKE-STEWART, A. \& DUNN, J. (eds) Families count: effects on child and adolescent development. New York: Cambridge University Press, 5-25.

MATTINGLY, M.J. \& DUGAN, L. 2008. How female victims' responses affect the risk of future assaults by their male intimate partners. In: KEELING, J. \& MASON, T. (eds) Domestic violence: a multi-professional approach for healthcare practitioners. England: Open University Press, 197-209.

McLEOD, C. 2011. Adolescence, pregnancy and abortion: constructing a threat of degeneration. East Sussex: Routledge.

McLEOD, J. \& NELSON, G. 2000. Programs for the promotion of family wellness and the prevention of child maltreatment: a meta-analytic review. Child Abuse \& Neglect, 24(9):1149-2000.

MINUCHIN, P., COLAPINTO, J. \& MINUCHIN, S. 2007. Working with families of the poor $\left(2^{\text {nd }} \mathrm{ed}\right)$. New York: Guilford Press.

MITCHELL, C.; THERON, L.; STUART, J.; SMITH, A. \& CAMPBELL, Z. (eds) 2011. Drawings as research method. In: THERON, L., MITCHELL, C., SMITH, A. \& STUART, J. Picturing research: drawing as visual methodology. Netherlands: Sense Publishers, 19-32.

MOLLBORN, S. 2006. Understanding teenage pregnancy norms and their influence on teenage mothers' and fathers' life outcomes. Dissertation, Standford University. In: SWARTZ, S. \& BHANA, A. 2009. Teenage Tata: voices of young fathers in South Africa. South Africa: HSRC Press.

MORKEL, E. 2011. A participatory approach to healing and transformation in South Africa. Family Process, 50(4):486-502.

MORRELL, R. \& RICHTER, L. 2006. BABBA: men and fatherhood in South Africa. In: PATRICK, C.L. 2006. Boys' experience of an absent father - A Gestalt therapeutic description. Pretoria: UNISA. (MA dissertation)

NATIONAL CENTRE ON FATHERS, FAMILIES, AND CHILD WELL BEING IN CAMEROON: A REVIEW OF THE LITERATURE. 2000. [Online] Available: http://www.ncoff.gse.ipenn.edu.

NATIONAL POPULATION UNIT. 2000. The state of South Africa's population report. Pretoria: Department of Social Development.

NIEUWENHUIS, J. 2007. Qualitative research designs and data gathering techniques. In: MAREE, K. (ed). First steps in research. Pretoria: Van Schaik Publishers, 69-97.

OOSTHUIZEN, M.J. \& NIEUWOUDT, L. 2002. A Poverty Profile of the Western Cape Province of South Africa. Stellenbosch University: Stellenbosch Economic Working Papers, 3/2002. 
POSSICK, C. 2005. Narratives of West Bank women settlers in "multi-problem families": a case of conflicting master-narratives. Narrative Inquiry, 15(2):405-420.

PRYOR, J. \& RODGERS, B. 2001. Children in changing families: life after parental separation. USA: Blackwell Publishing.

RANDO, T.A. 1993. Treatment of complicated mourning. Champaign, IL: Research Press.

RODRIGO, M.J., MÁIQUEZ, M.L., CORREA, A.D., MARTIN, J.C. \& RODRIGUEZ, G. 2006. Outcome evaluation of a community centre-based program for mothers at high psychosocial risk. Child Abuse \& Neglect, 30(9):1149-1064.

ROLEFF, T.L. 2000. Domestic violence: opposing viewpoints. California: Greenhaven Press.

ROSSMAN, B.B.R., HUGHES, H.M. \& ROSENBERG, M.S. 2000. Children and interparental violence: the impact of exposure. USA: Taylor 7 Francis.

SERUMAGA-ZAKE, P., KOTZE, D. \& MADSEN, R. 2005. A descriptive study of the dynamics of relative poverty in the Western Cape province of South Africa. Development Southern Africa, 22(1):143-160.

SHARLIN, S.A. \& SHAMIA, M. 2000. Therapeutic intervention with poor, unorganised families: from distress to hope. New York: Haworth Press.

SOUSA, L. \& EUSEBIO, C. 2005. When multi-problem poor individuals' values meet practitioners' values! Journal of Community and Applied Social Psychology, 15:353367.

SOUSA, L. 2005. Building on personal networks when intervening with multi-problem poor families. Journal of Social Work Practice, 19(2):163-179.

SOUSA, L., RIBIERO, C. \& RODRIQUES, S. 2007. Are practitioners incorporating a strengths-focused approach when working with multi-problem poor families? Journal of Community \& Applied Social Psychology, 17:53-66.

STATSSA 2001. Census 2001: stages in the life cycle of South Africans. [Online] Available: http://www.statssa.gov.za/census01/html/C2001Stages.pdf [Accessed 03/09/ 2011].

STATSSA 2009. Social profile of South Africa 2002-2009. [Online] Available: http://www.statssa.gov.za/publications/Report-03-19-00/Report-03-19-002009.pdf

[Accessed: 03/09/2011].

STRAUSSNER, S.L.A. \& FEWELL, C.H. 2010. Children of substance abusing parents: dynamics and treatment. New York: Springer Publishing Company.

STRYDOM, H. 2011. Sampling in the quantitative paradigm. In: DE VOS, A.S., STRYDOM, H., FOUCHÉ, C.B. \& DELPORT, C.S.L. (eds) Research at grass roots: for the social sciences and human service professions $\left(4^{\text {th }} \mathrm{ed}\right)$. Pretoria: Van Schaik Publishers, 222-235. 
SWARTZ, S. \& BHANA, A. 2009. Teenage Tata: voices of young fathers in South Africa. South Africa: HSRC Press.

TUTTY, I.M., ROTHERY, M.A. \& GRINNELL, R.M. 1996. Qualitative research for social workers: phases, steps and tasks. Boston, Mass: Allyn \& Bacon.

VAN EEDEN, J. 2011. Oh father where art thou? The Southern Independent Newspaper published on 21-06-2011. [Online] Available: http://www.iol.co.za/ sundayindependent/ life/oh-father-where-art-thou-1.1085989 [Accessed: 04/09/2011].

WALPER, S. \& BECKH, K. 2006. Adolescents' development in high conflict and separated families: evidence from a German longitudinal study. In: CLARKESTEWART, A. \& DUNN, J. (eds) Families count: effects on child and adolescent development. New York: Cambridge University Press, 238-270.

WELMAN, C., KRUGER, F. \& MITCHELL, B. 2005. Research methodology ( $3^{\text {rd }}$ ed). South Africa: Oxford University Press.

WHITTAKER, A. 2012. Research skills in social work. Glasgow: Sage Learning Matters.

WIDOM, C.S. \& MAXFIELD, M.G. 2001. An update on the "cycle of violence". Washington: National Institute of Justice.

WIEHE, V.R. 1998. Understanding family violence: treating and preventing partner, child, sibling, and elder abuse. California: Sage Publications.

WORLD BANK. 2008. Poverty and the environment: understanding linkages at the household level. Washington.

YONTEF, G. 1993. Awareness, dialogue and process: essays on Gestalt therapy. New York: Gestalt Journal Press.

ZUCKERMAN, B. 1994. Effects on parents and children. In: BESHAROW, D.J. (ed). When drug addicts have children. USA: CWLA, 49-63.

Mrs Jackie Hope was enrolled for a Masters in Social Work, North-West University, at the time of the research; Dr Mariette van der Merwe, Centre for Child, Youth and Family Studies, Faculty of Health Sciences, North-West University, Potchefstroom, South Africa. 